\title{
PHYTOCHEMICAL SCREENING AND ANTIMICROBIAL EVALUATION OF ETHANOLIC-AQUA EXTRACT OF Stachytarpheta jamaicensis (L.) VAHL LEAVES AGAINST SOME SELECTED HUMAN PATHOGENIC BACTERIA
}

\author{
Anthoney Swamy Thangiah \\ Senior Lecturer in Chemistry, Asia-Pacific International University, P.O. Box 4, Muak Lek, \\ Saraburi 18180, Thailand. \\ E-mail: drtanthony2011@yahoo.com
}

\begin{abstract}
The study was carried out to evaluate phytochemical and antibacterial effect of ethanolic-aqua extract of Stachytarpheta jamaicensis leaves against four selected pathogenic bacterial organisms.Phytochemical analysis revealed the presence of secondary metabolites such as tannins, saponins, terpenoids, flavonoids, phenols, alkaloids, steroids and glycoside. The zones of inhibitions were $11.503 \pm 0.005$ for B. cereus, $10.766 \pm 0.033$ for $S$. typhi, 14.766 \pm 0.0 .033 for $P$. vulgaris and $13.566 \pm 0.033$ for $S$. pyogenes respectively. The zones of inhibitions of the microorganism such as B. cereus, $P$. vulgaris and $S$. pyogenes were larger than their positive control except $S$. typhi. Analysis of variance (ANOVA) showed that the organisms were significantly different in the zones of inhibition $(p<0.05)$. The inhibition of the plant leaves extract to the growth of all the organisms greatly depicts the plant leaves to have great potential against diseases caused by the organisms. The overall therapeutic activities of the extract mighty be due to the presence of various phytoconstituents. Further research need to be done to prove their in vivo environment.
\end{abstract}

Keywords: Stachytarpheta jamaicensis, phytochemical, antibacterial, medicinal, plant, leaves, microorganism.

(C) RASĀYAN. All rights reserved

\section{INTRODUCTION}

Stachytarpheta Jamaicensis have been widely used by the people throughout the world for the various medicinal purposes. The plant grows $60-120 \mathrm{~cm}$ tall and has a smooth, dark green colored stem, which turns woody towards the base of the stem. ${ }^{1}$ These plants normally reproduce flowers in a mix of bluish and pinkish color or could bear flowers with a purple to deep blue color. Its leaves are greyish green in color has a smooth surface, and have a round apex and distinct petioles. This plant mostly grows in the tropical regions of America and other subtropical forests such as in Nigeria, Europe, and Russia. ${ }^{2}$ It is also widely distributed in acclimatized tropics such as those in Malaysia and Indonesia. S. jamaicensis referred to as "Jolok Cacing" or "Selasih Dandi" in these countries. ${ }^{3}$

The natural plants contain numerous medicinal values as well as nutraceuticals and phytochemicals uses. The folk medicine has been used for treating inflammatory disease, high blood pressure, hypertension etc. ${ }^{4}$ Many modern pharmaceuticals companies are using medicinal plants for various ailments since it has a good source of antioxidants for medical purposes. ${ }^{5}$ Since ancient time the traditional plants have been practiced, however, the isolation of active compounds such as morphine, quinine and alkaloids in the past two hindered years steered in the dawn of a new era in the use of medicinal plants and marked the beginning of modern research in the use of plants to cure diseases. ${ }^{6}$

About $80 \%$ of the population in some Asian and African countries still depend upon tradition herbal medicine for the prevention of many diseases. The use of medicinal plants as a fundamental component of the African traditional health care system is perhaps the oldest and most assorted of all the therapeutic systems. ${ }^{7}$

Rasayan J. Chem., 12(1), 300-307(2019)

http://dx.doi.org/10.31788/RJC.2019.1215042

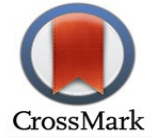


The medicinal plants have been tested extensively and found to have numerous pharmacological activity such as antibacterial, antifungal, antidiabetic, anticancer, antioxidant, hepatoprotective, haemolytic, antiinflammatory, larvicidal, anthelmintic, central nervous system and pain relief activity. ${ }^{8}$ It is very necessary to search for new antimicrobial agents due to an increase of antimicrobial resistance in recent years. Every year fifty thousand people are dying worldwide due to infectious disease. ${ }^{9}$ The products which are developed from the natural plants are a good source of new antimicrobials owes to low toxicity cause minimal environmental pollution and have a low risk of development of resistance by pathogenic microorganism. ${ }^{10}$ Some plants possess antimutagenic activity due to the presence of its total phenol and flavonoid content ${ }^{11}$ and certain aquatic plant-like watercress contains a promising level of pharmaceutical and nutritional sources. ${ }^{12}$

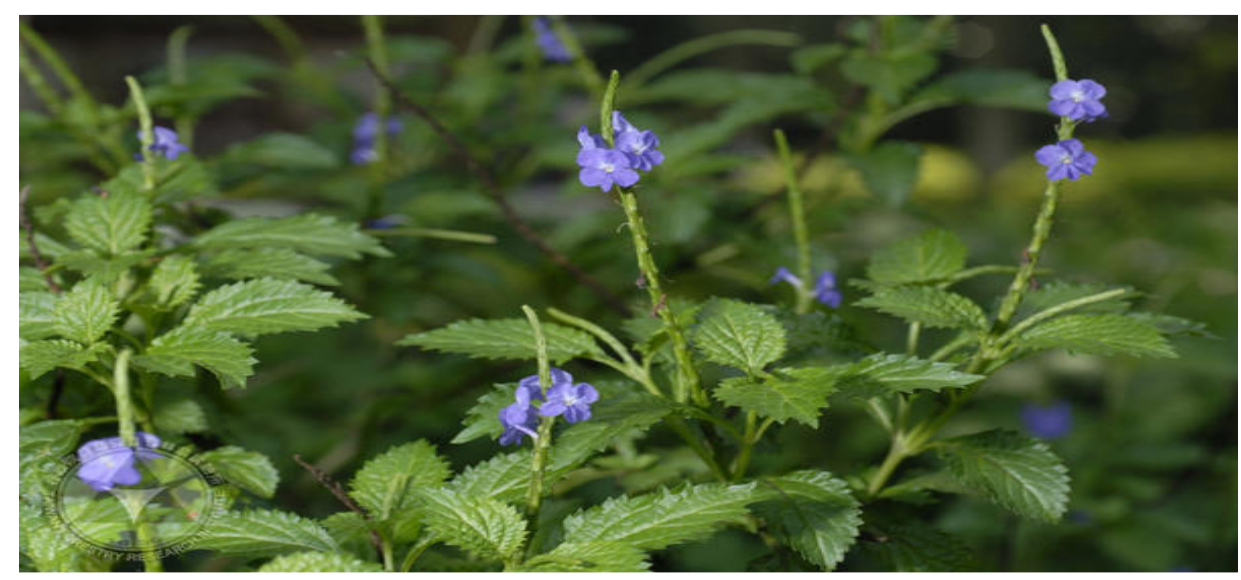

Fig.-1: Stachytarpheta jamaicensis (L.)

About one-half of mortality in tropical countries is due to infectious disease. In the modern technology world, in spite of advancement in the disease control, epidemics occurrence is due to drug-resistant microorganisms. Traditionally, plants provide a good source of anti-infective agents; emetine, quinine, and berberine remain highly effective instruments in the fight against microbial infections. The phytomedicines which are derived from the plants have great potential in the treatment of intractable infectious diseases including AIDS. The plants have traditionally provided a source of hope for novel drug compounds, as plant herbal mixtures have made large contributions to human health and well-being. The use of plant extracts with known antimicrobial properties can be of great significance for therapeutic treatment. ${ }^{13}$

The stem and leaf extract of $S$. jamaicensisare usually prepared in the form of a tea bag and have been extensively used by the elderly as a cooling tonic for the stomach problem. This cooling tonic is consumed to stimulate the function of the gastrointestinal tract or to aid in digestive problems such as indigestion, acid reflux, ulcers, constipation, dyspepsia, and slow digestion. ${ }^{14}$

The aqueous extracts of $S$. jamaicensisleaves have been used to cure colic, chest colds, cough and dysentery ${ }^{15}$, and its infusion have been used as a remedy for a headache. ${ }^{16}$ The aim of this study was to investigate phytochemical screening and antimicrobial evaluation of ethanolic-aqua extract of Stachytarpheta jamaicensis leaves against four selected human pathogenic bacteria.

\section{Extraction Procedure}

\section{EXPERIMENTAL}

The Stachytarpheta jamaicensis leaves were randomly collected from the natural forest. The samples were spread to dry at room temperature in the laboratory for about three weeks and then grounded into fine powder. Using electric analytical beam balance fifty grams of the powdered leaves of the Stachytarpheta jamaicensis was placed in $1000 \mathrm{ml}$ conical flask, ethanol and water were then added in the ratio of 9:1 respectively until the leaves were completely submerged in the solvent. The mixture was then agitated for thorough mixing. The mixture was kept for 24 hours on a shaker for effective extraction of the plant components. The extract was filtered using Buchner funnel; Whatman no.1 filter paper and a vacuum pressure pump. The filtrate was re-filtered again using the same apparatus. The solvent was evaporated 
RASĀYAN J. Chem.

Vol. 12 | No. 1 |300 - 307| January - March | 2019

using rotary vacuum evaporator (R-11) with a water bath at $40^{\circ} \mathrm{C}$. The extract was brought to dryness using a vacuum pressure pump at room temperature. The residue was then obtained and used for the experiment.

\section{Preliminary Phytochemical Screening}

The phytochemical screening for the identification of secondary metabolites was done using standard procedures. ${ }^{17-20}$

\section{Tannins}

About $0.5 \mathrm{~g}$ of the sample was put in a test tube and $20 \mathrm{ml}$ of distilled water was added and heated to boiling. The mixture was then filtered and $1 \%$ of $\mathrm{FeCl}_{3}$ was added to the filtrate and observations made. Brownish green coloration indicates the presence of tannins.

\section{Saponins}

The crude extract was mixed with $5 \mathrm{ml}$ of water and vigorously shaken. The formation of stable form indicates the presence of saponins.

\section{Flavonoids}

To a portion of the aqueous extract, $5 \mathrm{ml}$ of dilute ammonia and $2 \mathrm{ml}$ of concentrated sulphuric acid were added. The appearance of a yellow color indicates the presence of flavonoids.

\section{Terpenoids}

To a portion of the plant extract, $2 \mathrm{ml}$ of chloroform was added and shaken vigorously, then evaporated to dryness. To this content, $2 \mathrm{ml}$ of concentrated sulphuric acid was added and heated for about 2 minutes. A greyish color indicates the presence of terpenoids.

\section{Glycosides (Salkowsks' Test)}

The extract of the plant material was mixed with $2 \mathrm{ml}$ of chloroform, and $2 \mathrm{ml}$ of concentrated sulphuric acid was added carefully and shaken gently, then the observations were made. A red-brown color indicates the presence of steroidal ring (glycone portion of glycoside).

\section{Alkaloids}

The crude extract was mixed with $1 \%$ of $\mathrm{HCl}$ in a test tube. The test tube was then heated gently and filtered. To the filtrate, a few drops of Mayer's and Wagner's reagents were added to the test tube. A resulting precipitate confirmed the presence of alkaloids.

\section{Steroids (Liebermann Burchard Reaction)}

To $2 \mathrm{~g}$ of the extract, $10 \mathrm{ml}$ of chloroform and $2 \mathrm{ml}$ of acetic anhydride were added. Then concentrated sulphuric acid was added along the side of the test tube in an inclined position. Bluish-green ring indicates the presence of steroids.

\section{Phenols}

To $2 \mathrm{gm}$ of the extract few drops of $2 \%$ of $\mathrm{FeCl}_{3}$ was added. A bluish-green or black coloration indicates the presence of phenols.

\section{Bioassay Study}

\section{Preparation of the Extract Concentration and Positive Control}

Stock solutions for the extracts were prepared by dissolving $500 \mathrm{mg}$ in $1 \mathrm{ml}$ of dimethylsulfoxide (DMSO). An antibiotic control was made by dissolving $1 \mu \mathrm{g}$ of penicillin in $1 \mathrm{ml}$ of sterile distilled water. DMSO served as a negative control.

\section{Tested Microorganisms}

The microorganism used for the bioassay were Bacillus cereus, Salmonella typhi, Proteus vulgaris and Streptococcus pyogenes.

\section{Preparation of the Bacterial Suspension}

The turbidity of each of the bacterial suspension was prepared to match to a $0.5 \mathrm{McFarland}$ standard, a procedure similar to that used by Donay. ${ }^{21}$ The McFarland standard was prepared by dissolving $0.05 \mathrm{~g}$ of $\mathrm{BaCl}_{2}$ in $50 \mathrm{ml}$ of water to obtain a $1 \%$ solution of Barium chloride (w/v). This was mixed with $99.5 \mathrm{ml}$ of 
$1 \%$ sulphuric acid solution. Three to five identical colonies of each bacterium was taken from a blood agar plate (Himedia) culture and dropped in Mueller Hinton broth (Himedia). The broth culture was incubated at $37^{\circ} \mathrm{C}$ for $2-6$ hours until it achieved turbidity similar to the $0.5 \mathrm{McF}$ arland standards. The culture that exceeded the $0.5 \mathrm{McF}$ arland standard were each adjusted with the aid of a UV spectrophotometer to $0.132 \mathrm{~A}^{\circ}$ at a wavelength of $600 \mathrm{~nm}$ in order to obtain an approximate cell density of $1 \times 10^{8} \mathrm{CFU} / \mathrm{ml} .^{17}$

\section{Determination of Bioactivity of the Extract}

Brain heart infusion agar plates were prepared by the manufacturer's instruction, $0.1 \mathrm{ml}$ of each of the prepared bacterial suspension for the test was transferred to 3 plates for each organism to give a triplicate for each concentration and organism. Three wells were drilled in each agar plate. One of the wells was filled with the extract dilution and the other wells were filled with the positive control Penicillin and negative control DMSO control respectively. Three plates were made for each bacterial organism and extract giving a triplicate reading for each microorganism and extract. The wells were labeled on the underside of the plate. The plates were incubated at $37^{\circ} \mathrm{C}$ for between 24 to 48 hours and the zones of inhibition were measured in millimeters with the aid of a ruler. ${ }^{17}$

\section{Statistical Analysis}

Bioactivity analysis values were expressed as a mean \pm standard $(\mathrm{mm} \pm$ S.E.) and Turkey's post hoc test was carried out to analyze the significant difference between different groups using the statistical analysis software package SPSS version-13. Values with $\mathrm{P}<0.05$ were considered as significant.

\section{Phytochemical Analysis of Extract}

\section{RESULTS AND DISCUSSION}

The phytochemical analysis of an ethanolic-aqua extract of Stachytarpheta jamaicensis indicated the presence of different kinds of secondary metabolites such as tannins, saponins, terpenoids, flavonoids, phenols, alkaloids, steroids and glycoside. These bioactive compounds are responsible for therapeutic activities. The secondary metabolite tannin is exhibiting antibacterial and antioxidants activities and also react with proteins to provide the typical tanning effect. ${ }^{22,23}$ The phytochemical content of plants playing a significant contribution towards antibacterial activity. ${ }^{24}$

Table-1: Phytochemical Analysis for Stachytarpheta jamaicensis Leaves

\begin{tabular}{c|c|c}
\hline Phytochemical & Observation & Inferences \\
\hline Tannins & Bluish-black color & Present \\
\hline Saponins & Stable foam & Present \\
\hline Terpenoids & Grey color & Present \\
\hline Flavonoids & Yellow Colour & Present \\
\hline Phenols & Black coloration & Present \\
\hline Alkaloids & Precipitate & Present \\
\hline Steroids & Bluish green ring & Present \\
\hline Glycoside & Red-brown & Present \\
\hline
\end{tabular}

Tannins are mordant plant phenolic compounds used therapeutically as antimicrobial, anti-inflammatory, antidiarrheal, haemostatic and antihemorrhoidal. ${ }^{25}$ The secondary metabolites such as saponins, tannins and flavonoids present in the plant $S$. jamaicensis exhibiting antimicrobial activities against the microorganism E.coli, C. albicans, S. aureus and P. vulgaris. ${ }^{14}$

Due to the presence of tannins in the natural product can be used in the treatment of HFE hereditary hemochromatosis, a hereditary disease characterized by excessive absorption of dietary iron resulting in a pathological increase in total body iron stores. Tannins can also be used to stop infection while they continue to heal the wounds, burns and stop bleeding internally. Tannins have been used for immediate relief of sore throats, diarrhea, dysentery, hemorrhage, fatigue, skin ulcers and also very effective for protecting the kidney. ${ }^{26}$ 
RASĀYAN J. Chem.

Vol. 12 | No. 1 |300 - 307| January - March | 2019

Due to the high phenolic content in the methanolic extract of $S$. jamaicensis leaves shows exceptional antioxidant and therapeutic potentials because the phenolic constituents can react with active oxygen radicals such as hydroxyl radical, superoxide anion radical and lipid peroxy radical. ${ }^{27,} 28$ The foremost medicinal activities of the leaf extract of $S$. jamaicensis is due to the presence of phenolic and flavonoid compounds. ${ }^{25}$ Consumption of flavonoids has protective effects in immunomodulation, cognition, and risk reduction of certain cancers, cardiovascular and skin diseases, neurodegenerative disorders, osteoporosis and obesity, as well as relief of menopausal symptoms. ${ }^{29}$

\section{Antibacterial Activity}

The ethanolic-aqua extract of Stachytarpheta jamaicensis was active against Bacillus cereus, Salmonella typhi, Proteus vulgaris and Streptococcus pyogenes. Penicillin was used as the positive control and Dimethyl sulfoxide (DMSO) as a negative control. The zones of inhibitions were $11.503 \pm 0.005$ for $B$. cereus, $10.766 \pm 0.033$ for $S$. typhi, $14.766 \pm 0.0 .033$ for $P$. vulgaris and $13.566 \pm 0.033$ for $S$. pyogenes respectively (Table 2). The zones of inhibitions of their positive controls were $10.933 \pm 0.333$ for $B$. cereus control, $9.806 \pm 0.013$ for $S$. typhi control, $15.080 \pm 0.060$ for $P$. vulgaris control and $12.966 \pm 0.033$ for $S$. pyogenes control. The plant extract showed the highest average zone of inhibition against $P$. vulgaris followed by S. pyogens, B. cereus and S. typhi.

Table-2: Zone of inhibition ( $\mathrm{mm} \pm$ S.E.) of ethanolic-aqua Extract of Stachytarpheta jamaicensis against selected Bacterial Organisms

\begin{tabular}{l|c|c|c}
\hline \multicolumn{1}{c|}{ Microorganism } & $\begin{array}{c}\text { Zone of Inhibition }(\mathrm{mm} \pm \\
\text { S.E. })\end{array}$ & $\begin{array}{c}\text { Penicillin Control } \\
(\mathrm{mm} \pm \text { S.E. })\end{array}$ & $\begin{array}{c}\text { DMSO control } \\
(\mathrm{mm} \pm \text { S.E. })\end{array}$ \\
\hline Bacillus cereus & $11.503 \pm 0.005$ & $10.933 \pm 0.333$ & $0.00 \pm 0.000$ \\
\hline Salmonella typhi & $10.766 \pm 0.033$ & $9.806 \pm 0.013$ & $0.00 \pm 0.000$ \\
\hline Proteus vulgaris & $14.766 \pm 0.033$ & $15.080 \pm 0.060$ & $0.00 \pm 0.000$ \\
\hline Streptococcus pyogenes & $13.566 \pm 0.033$ & $12.966 \pm 0.033$ & $0.00 \pm 0.000$ \\
\hline
\end{tabular}

Key: S.E. $=$ Standard Error; $\quad$ DMSO = Dimethyl Sulfoxide

The extract of Stachytarpheta jamaicensis leaves exhibited the highest activity against the microorganism B. cereus, S. typhi and S. pyogenes than their positive control, however, the zones of inhibition of the extract was smaller for $P$. vulgaris than their positive control. There was no zone of inhibition produced by the negative control DMSO against the microorganism tested, i.e., the zones of inhibitions for the negative control DMSO were $0.00 \pm 0.000$. A one-way analysis of variance (ANOVA) showed that all the organisms were significantly different from and their controls.

On further Tukey's pair wise comparison test shows that the positive control's zones of inhibition were significantly lower than the extract concentration against the microorganism B. cereus, $P$. vulgaris and $S$. pyogenes, however, higher for $P$. vulgaris $(\mathrm{P}<0.05)$. Tukey's comparisons results have shown that the zone of inhibitions for $P$. vulgaris was significantly bigger than all the organisms tested against but significantly smaller than its positive control $(\mathrm{P}<0.05)$.

The plant extracts have the ability to promote drug accumulation in bacterial cells. ${ }^{30}$ The ethanolic extract of Stachytarpheta jamaicensis was capable of causing damage to the Bacillus cereus, Salmonella typhi, Proteus vulgaris and Streptococcus pyogenes. DMSO did not cause damage to the bacterial membranes as the protein and nucleic acid leakage from the bacterial cells did not change significantly when the cells were exposed to DMSO.

In vitro activities of ethanolic extract of fifty plants were screened against gram-negative bacteria such as E. coli and Pseudomonas aeruginosa and Gram-positive bacteria Staphyloccocus aureus, Enterococcus faecalis, Streptococcus pyogenes and Bacillus subtilis bacteria. Thirty-one extracts showed antibacterial activity only on Gram-positive bacteria. Of these, ten extracts from ten plant species had a promising level of activity against bacteria including strains resistant to antibiotics such as aminosides, penicillin $\mathrm{M}$, macrolides, lincosamide and streptrogramin $\mathrm{B} .{ }^{31}$

The methanolic extract of $S$. jamaicensis have shown antibacterial activity against the microorganism $E$. coli, Staphylococcus epidermis and Pseudomonas aeruginosa with a moderate zone of inhibition. ${ }^{32}$ 
RASĀYAN J. Chem.

Vol. 12 | No. 1 |300 - 307| January - March | 2019

The antibacterial activities of aqueous extract of $S$. jamaicensis leaves showed varying inhibition on $B$. subtillis, E. coli, Candida albicans, Staphylococcus aureus, Pseudomonas aureginosa, Proteus vulgaris, Klebsiella arogene and Proteus mirabilis whereas the alcoholic extract of $S$. jamaicensis leaf showed slight inhibition on Staphylococcus aureus and Proteus vulgaris. ${ }^{14}$

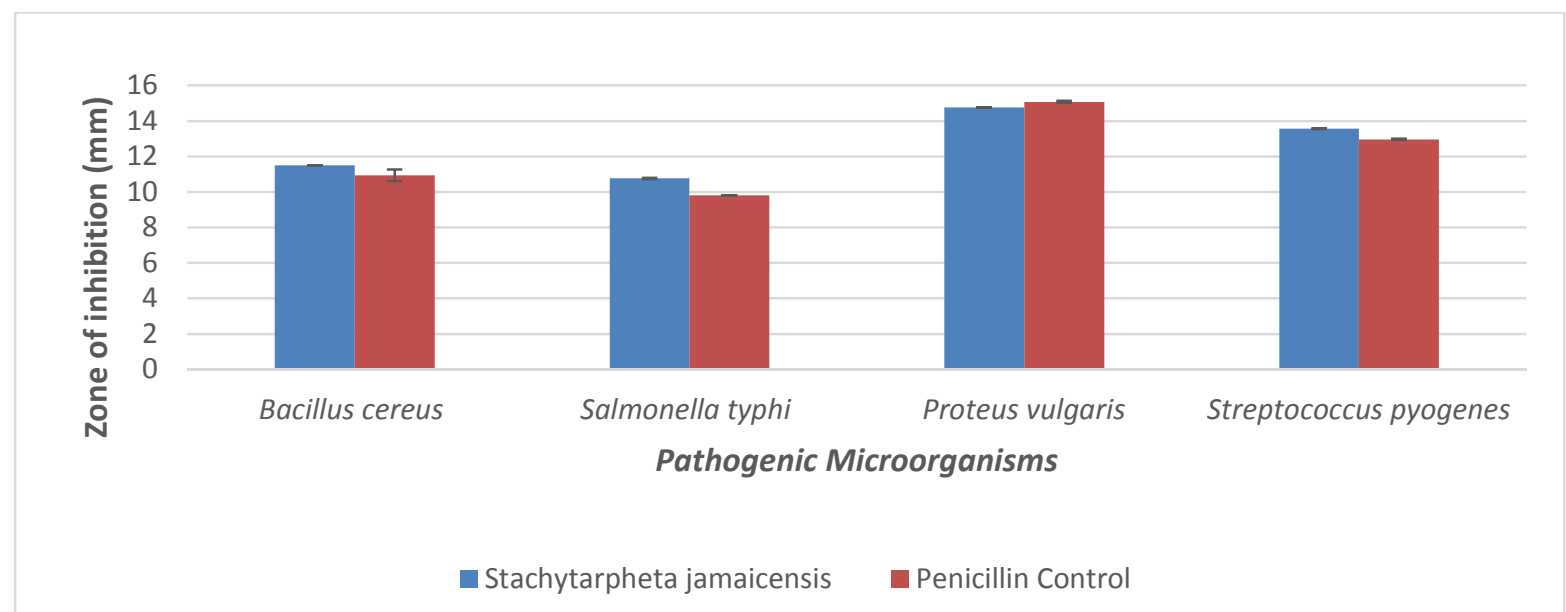

Fig.-2: Zone of Inhibition of Ethanolic - Aqua Extract of Stachytarpheta jamaicensis against Selected Bacterial Organisms

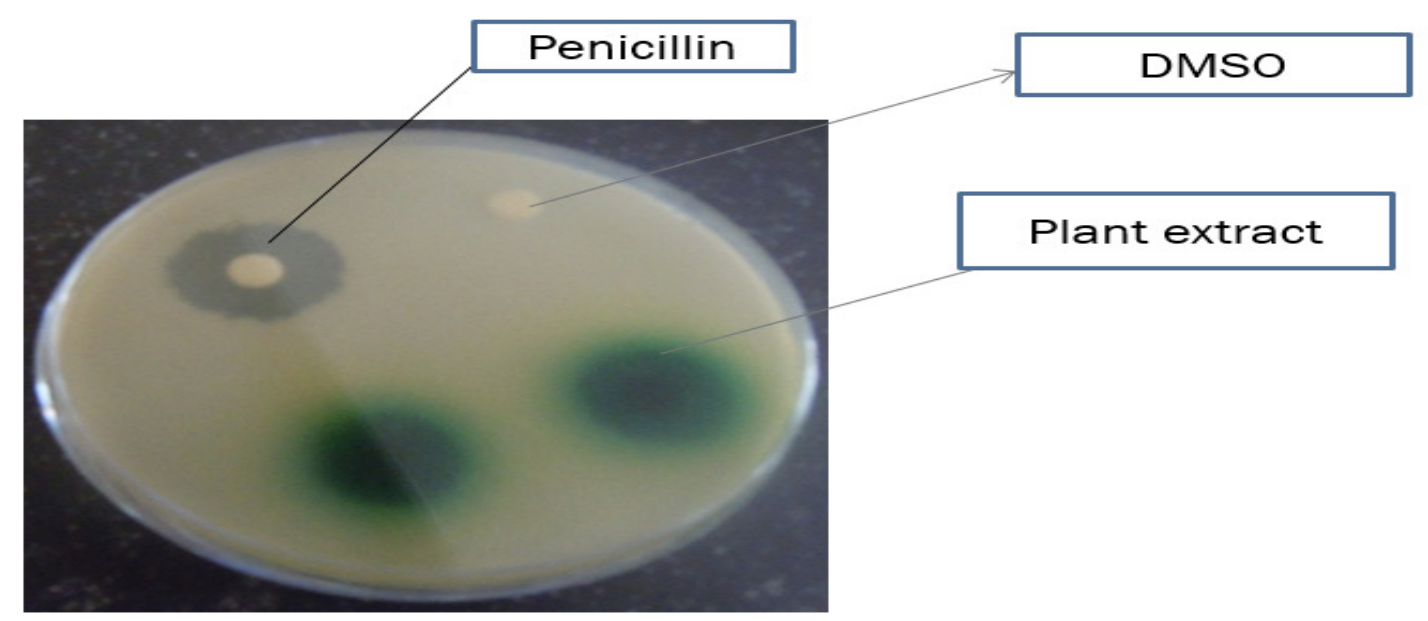

Fig.-3: Antibacterial Activity of Stachytarpheta jamaicensis against Streptococcus pyogenes

The methanolic extract of $S$. jamaicensis leaves in castor oil and magnesium sulphate-induced (causative organisms of diarrhea) diarrhea models in vivo and the evidence from this research have shown that the methanol extract of $S$. jamaicensis possessed a significantly high volume of antidiarrheal activity in Swiss albino mice, in a dose-dependent manner. ${ }^{32,33}$ The antimicrobial activity of the three parts of the plant $S$. jamaicensis such as roots, stem, and leaves have shown activity against Pseudomonas aeruginosa, Micrococcus luteus, and Escherichia coli. The crude root extract showed better antimicrobial activity against Pseudomonas aeruginosa compared to other crude extracts. ${ }^{34}$ The aqueous extract of $S$. jamaicensis showed that extract has no toxic toward Wistar rats even up to a dose of $4 \mathrm{~g} / \mathrm{kg}$ body weight and no significant changes in body weight on Wistar rats. ${ }^{14}$

The methanol extract of $S$. jamaicensis leaves exhibited antidiarrheal activity in a number of models of diarrheic conditions in test mice along with antimicrobial activity, the extract could be used as a nonspecific treatment for diarrhea and the methanolic extract might be effective in inflammatory diarrhea, secretory diarrhea, and infectious diarrhea. Hence, its leaves may be used as a potential source for a novel 'lead' discovery for antidiarrheal drug development. ${ }^{32}$ 
RASĀYAN J. Chem.

Vol. 12 | No. 1 |300 - 307| January - March | 2019

Since the S. jamaicensis plant being resistant to some strains of clinical microorganisms especially the fungi and bacteria at high concentration ascertain that it is a possible antibiotic which should be administered high doses. Thus, S. jamaicensis plant is relatively safe for the therapeutic cure of diseases and could be potentially beneficial to human. ${ }^{14}$

From the data obtained in this study, it is clear that the ethanolic aqua extract of Stachytarpheta jamaicensis leaves has a great potential in limiting the spread of pathogenic bacterial organisms such as Bacillus cereus. Salmonella typhi, Proteus vulgaris and Streptococcus pyogens. Therefore, it is worthy to mention that the plant can be used to treat against all the infections caused by the above-mentioned microorganism.

\section{CONCLUSION}

As a conclusion, the phytochemical analysis revealed the presence of various active phytoconstituents. The antibacterial activities of an ethanolic aqua extract of Stachytarpheta jamaicensis leave to play a substantial role in medicinal systems because of its significant inhibit action against all the four tested microorganisms, hence, its leaves can be used as an antibacterial agent against diseases caused by the tested microorganisms. The overall therapeutic activities of the leaf extract of Stachytarpheta jamaicensis might be due to the presence of its various secondary metabolites. Since the pharmaceutical company is looking forward to developing new drugs every day and they can consider this medicinal plant for the treatment of diseases. However, more investigation needs to be carried out scientifically to prove the efficacy of this plant as well as further studies on its toxicity effect. Since the natural medicinal plants are being very cheap and safer than synthetic medicines, the medicine which may develop from this plant might help the community with the aim for a better economic and beneficial utilization.

\section{REFERENCES}

1. M. Idu, J.O. Erhabor and E.A. Odia, Ethnobotanical Leaflets,13(11), 1417(2009).

2. K. Ramakrishnan and R. Sivaranjani, International Research Journal of Pharmacy, 4(10), 44(2013), DOI: $10.7897 / 2230-8407.041011$.

3. M.R. Sulaiman, Z.A. Zakaria, H. S. Chiong, S. K. Lai, D.A. Israf and T.M.A. Shah, Medical Principles and Practice, 18(4), 272(2009), DOI: $10.1159 / 000215723$

4. J.A.O. Olugbuyiro, A.S. Banwo, A.O. Adeyemi, O.S. Taiwo and O.A. Akintokun, Rasayan J. Chem.,11(2), 798(2018), DOI:10.31788/RJC.2018.1121823.

5. J.T. Kumplulainen and J.T. Salonen, Natural Antioxidants and Anticarcinogens in Nutrition, Health and Disease, The Royal Society of Chemistry, UK, p.178,187(1999).

6. C. Veeresham, Journal of Advanced Pharmaceutical Technology and Research, 3(4), 200(2012), DOI: $10.4103 / 2231-4040.104709$.

7. M.F.A. Baker, M. Mohamad, A. Rahmat, S.A. Burr and J.R. Fry, Food Chem Toxicol, 48(6), 1688(2010), DOI: 10.1016/j.fct.2010.03.046.

8. J.M. Andrade, C. Faustino, C. Garcia, D. Ladeiras, C.P. Reis and P. Rijo, Future Science OA, 4(4), 1(2018), DOI: $10.4155 /$ fsoa-2017-0124.

9. http://www.who.int/whr/1996/media_centre/press_release/en/.

10. E.R. Mbega, C.N. Mortensen, R.B. Mabagala and E.G. Wulff, Journal of General Plant Pathology, 78(4), 277(2012), DOI: 10.1007/s10327-012-0380-z.

11. Sumaiyah, Masfria and A. Dalimunthe, Rasayan Journal of Chemistry, 11(2), 505(2018), DOI:10.31788/RJC.2018.1122068.

12. G. Haro, I. Iksen, R.M. Rumanti, N. Marbun, R.P. Sari and R.P.J. Gultom, Rasayan J. Chem.,11(1), 232(2018), DOI:10.7324/RJC.2018.1112011

13. M.W. Iwu, A.R. Duncan and C.O. Okunji, New antimicrobials of plant origin. In: J. Janick (ed.), Perspectives on new crops and new uses. ASHS Press, Alexandria, VA, p.457, 462(1999).

14. M. Idu, E.K.I. Omogbai, G.E. Aghimien, F. Amaechina, O. Timothy and S.E. Omonigho, Trends in Medical Research, 2(4), 193(2007), DOI: 10.3923/tmr.2007.193.198.

15. C. Penido, K.A. Costa, D.O. Futuro, S.R. Paiva, M.A. Kaplan and M.R. Figuciredo, Journal of Ethnopharmacology,104(1-2), 225(2006), DOI: 10.1016/j.jep.2005.09.006. 
RASĀYAN J. Chem.

Vol. 12 | No. 1 |300 - 307| January - March | 2019

16. J.O. Kokwaro, Medicinal plants of east Africa, Nairobi: University Press, $3^{\text {rd }}$ edition, Nairobi, pp.292(2009).

17. C.S. Mutuku, A.S. Thangiah, and J.K. Obey, Int. J. Bioassays, 2(7), 1037(2013), DOI: 10.21746/ijbio.2013.07.0017

18. G.E. Trease and W.C. Evans, 1989, Pharmacognosy, $11^{\text {th }}$ Edition, Brailliere Tindall, London. pp.4550.

19. J.B. Harborne, 1973, Phytochemical methods Chapman and hall ltd, London, pp.49-188

20. A. Sofowara, 1993, Medicinal plants and traditional medicine in Africa. Spectrum Books Ltd, Ibadan Nigeria, pp.191-289.

21. J.L. Donay, P. Fernandes, P.H. Lagrange and J.L. Herrmann, Journal of Clinical Microbiology, 45(12), 4088(2007), DOI: 10.1128/JCM.01847-07.

22. A.E. Hagerman and I.G. Butler, J. Biol. Chem., 256(9), 4494(1981).

23. G.E. Trease and W.C. Evans, Textbook of Pharmacognosy, $12^{\text {th }}$ Edition, Balliere, Tindall, London, pp 57,343(1983).

24. D.U.C. Rahayu, Hartono and P. Sugita, Rasayan Journal of Chemistry, 11(2), 762(2018), DOI:10.31788/RJC.2018.1122076.

25. Z.S. Ololade, O.O. Ogunmola, S.E. Kuyooro, O.O. Abiona, Journal of Scientific and Innovative Research, 6(4), 119(2017).

26. A.A. Bele, V.M. Jadhav and V.J. Kadam, Asian Journal of Plant Sciences, 9(4), 209(2010), DOI: 10.3923/ajps.2010.209.214.

27. G.S. Celep, R. Rastmanesh, Journal of Nutritional Disorders \& Therapy, 3(1), 1(2013), DOI: $10.4172 / 2161-0509.1000 \mathrm{e} 106$.

28. C. Cueva, I. Gil-Sanchez, B. Ayuda-Duran, S. González-Manzano, A.M. Gonzalez-Paramas, C. Santos-Buelga, B. Bartolomé and M.V.Moreno-Arribas, Molecules, 22(1), 1(2017), DOI:10.3390/molecules22010099.

29. C. Nguyen, J.F. Savouret, M. Widerak, M.T. Corvol and F. Rannou, Nutrients, 9(1), 45(2017), DOI: 10.3390/nu9010045.

30. Y.C. Fiamegos, P.L. Kastritis and V. Exarchou, PLoS ONE, 6(4), 1(2011), DOI: 10.1371/journal.pone.0018127.

31. W.M. Kone, K.A. Kamanzi, C. Terreaux, K. Hostettmann, D. Trapre and M. Dosso, Journal of Ethnopharmacology, 93(1), 43(2004), DOI:10.1016/j.jep.2004.03.006.

32. S. Sasidharan, L.Y. Latha, Z. Zuraini, S. Suryani, S. Sangetha and L. Shirley, Indian J. Pharmacol., 39(5), 245(2007), DOI: 10.4103/0253-7613.37276

33. M.L. Pearl and K.T. Yoke, Evid Based Complement Alternat Med., 2016(10), 1(2016) DOI: $10.1155 / 2016 / 7842340$.

34. I. Putera and S.K. Anis, M.Sc. Dissertation, Faculty of Biosciences and Bioengineering, University Technology Malaysia, Malaysia (2010).

[RJC-5042/2017] 